\title{
Agnew, ABC, and Richard Nixon's War on Television
}

Dale L. Cressman PhD

Brigham Young University - Provo, cressman@byu.edu

Follow this and additional works at: https://scholarsarchive.byu.edu/facpub

Part of the Social Influence and Political Communication Commons, and the Television Commons

Original Publication Citation

Journalism History Vol 46 (no. 4) DOI 10.1080/00947679.2020.1845042

\section{BYU ScholarsArchive Citation}

Cressman, Dale L. PhD, "Agnew, ABC, and Richard Nixon's War on Television" (2020). Faculty Publications. 4484.

https://scholarsarchive.byu.edu/facpub/4484

This Peer-Reviewed Article is brought to you for free and open access by BYU ScholarsArchive. It has been accepted for inclusion in Faculty Publications by an authorized administrator of BYU ScholarsArchive. For more information, please contact ellen_amatangelo@byu.edu. 


\title{
Agnew, ABC, and Richard Nixon's War on Television
}

\author{
Accepted Manuscript for Journalism History Vol. 46 (no. 4) December 2020 \\ Routledge - https://doi.org/10.1080/00947679.2020.1845042 \\ (C) 2020 History Division of the AEJMC
}

\section{DALE L. CRESSMAN \\ School of Communication, Brigham Young University, Provo, Utah, USA}

\begin{abstract}
Less than a year into the presidency of Richard Nixon, Vice President Spiro Agnew launched a series of attacks on television journalists, accusing them of being biased and having too much power to determine what news millions of Americans watched on their televisions. Because the government licensed and regulated their stations, the networks considered Agnew's statements, and other White House criticisms, to be threats. As the smallest, most vulnerable network, $\mathrm{ABC}$ found itself at a confluence of relationships with the administration: It employed both Nixon's favorite and least favorite anchors, as well as a highly placed executive who lent sympathy and assistance to the White House. In addition, one of ABC's senior correspondents went to work for the president. Finally, the network aired a popular television program with the assistance of the FBI. This article focuses on ABC during the Nixon administration's war on television news.
\end{abstract}

Keywords: Network television news; Richard Nixon; Spiro Agnew; television; White House

Network news executives received on Nov. 14, 1969, an advance copy of a speech that Vice President Spiro Agnew was to give at a regional Republican Party meeting in Des Moines, Iowa, later in the day. The subject of the speech was television news itself. The vice president planned to question the networks' impartiality and attack broadcast journalism's credibility. ABC, CBS, and NBC all scrambled to arrange to carry the speech live.

After the broadcast of Agnew's speech, in which he described television journalists as an elite and biased "small band," network television journalists believed their freedom of expression was more vulnerable than ever before. One news executive, CBS's Richard Salant described the speech as the "shot heard around the . . broadcast world." It was, according to scholar Michael Socolow, "the most influential indictment of American journalism ever made," while Jill Lepore asserts that "No scholar of journalism can afford to ignore Agnew anymore."1

The substance of Agnew's speech should not have come as a surprise to broadcasters: Richard M. Nixon's dislike of the news media was well known long before he was elected president. His friends characterized it as a "fervid hatred," something "close to irrational animus." Long-time Nixon aide Herbert Klein said Agnew felt similarly; both distrusted the media and would "coil back [and] pull away in a sea of bitterness." What was surprising to many members of the news media was the "chilling . . . harshness and bellicosity" with which Agnew lashed out. As David Halberstam has noted, "This was a man looking for a fight."2

\section{https://journalism-history.org}


Seemingly tame when compared to presidential discourse during Donald J. Trump's administration, Agnew's speech, less than a year into Nixon's first term, was an inflection point in the relationship between journalists and the presidency. As scholar Matthew Pressman has suggested, journalism became more adversarial during this period, resulting in the perception that the role of reporters had changed "from stenographer to analyst." the government had so directly assailed television networks, which were beholden to the Federal Communications Commission (FCC), a government agency that not only licensed their affiliated television stations but also served as watchdog to ensure they were operating in the "public interest, convenience, and necessity." 4 Six years earlier, during John F. Kennedy's administration, the idea that a president and his staff were subtly seeking to "manage" the news by "favoring friendly reporters" and "harassing unfriendly critics" was scandalous enough to be headlined on magazine covers. ${ }^{5}$

Kennedy's successor, Lyndon Johnson, later advised Agnew, "Young man, we have in this country two big networks, NBC and CBS. ... They're so damned big they think they own the country." 6 The Nixon White House rejected that proposition, as well as the notion that journalists were unbiased messengers. In fact, Nixon was the first president to regard the press as a political rival and to attack it as such. ${ }^{7}$ Marvin Kalb, a former television news correspondent, dubbed the Nixon administration's approach "Agnewism."

More than forty years later, the Trump administration used similar methods to frame journalistic entities as political opponents and diminish their credibility. As a candidate and as president, Trump threatened to weaken libel laws to make it easier to sue journalists; he characterized journalism as "fake news" and famously called the press the "enemy of the people." Examinations of the Nixon administration's approach to the press are warranted because Agnewism may have served, wittingly or not, as a template for the Trump administration's treatment of the press.

Tellingly, when Johnson opined on the power of television networks in 1968, he mentioned only two of them. The third, $\mathrm{ABC}$, was not even considered in many discussions. It was the weakest network, the financially poorest network; it was watched in fewer homes than its competitors were and had the fewest number of television stations carrying its newscasts. While CBS and NBC battled it out with the industry's top anchors and reporters, ABC struggled to hire talent, to equip itself with the latest technology, to survive. It did not have its own film crews until 1963 and expanded its newscasts from fifteen minutes to thirty minutes a full four years after CBS and NBC did so. In 1968, after converting from black-and-white to color television, ABC's finances became even more precarious, and only worsened when the Justice Department scuttled its proposed merger with ITT. Although resurgent through the latter part of the 1970s and dominant in the 1990s, ABC was hardly removed from a time when its competitors jokingly referred to it as the "Almost Broadcasting Company." 10 If CBS and NBC were concerned by perceived government intimidation, $\mathrm{ABC}$ had reason to fear it.

\section{https://journalism-history.org}


This article describes a moment in which the relationship between television networks and the government became more directly adversarial, when Vice President Agnew and White House aides publicly and directly attacked television journalism with implied threats to the networks' licenses. Furthermore, it breaks new ground in describing how the administration privately leveraged a unique confluence of relationships with the weakest of the three television networks. For example, during Nixon's first term, a long-time ABC News diplomatic correspondent was granted leave to accept an appointment as a counselor to the president on communications and foreign policy issues. Additionally, one of ABC's anchors was a White House favorite who reciprocated its favorable treatment of him with positive commentaries on the ABC Evening News and social visits with the president. Of particular significance is James Hagerty's role as ABC's executive vice president for corporate relations. Hagerty (Figure 1), who had previously served for eight years as President Dwight D. Eisenhower's press secretary, and then as the head of ABC News until he was succeeded by Elmer W. Lower in 1963, provided the administration with a back channel to his network, along with sympathy and advice. ${ }^{11}$ Hagerty's effort to persuade J. Edgar Hoover to save his network's ongoing broadcast of the drama The FBI sheds new light on his own representation of his influence on $A B C$ News, as well as the circumstances surrounding the dismissal of an $\mathrm{ABC}$ anchor the White House fervently disliked.

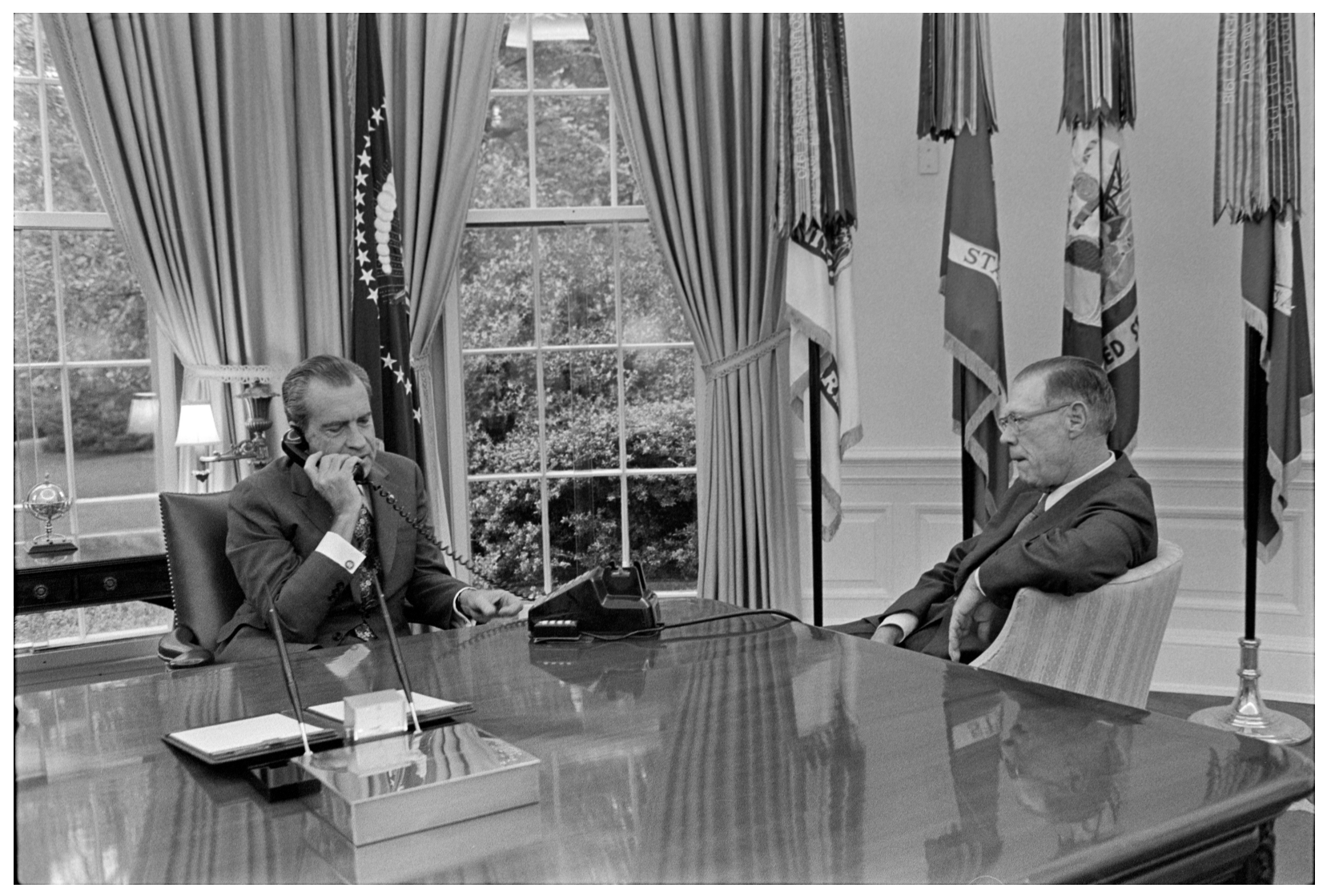

James Hagerty in Oval Office with President Nixon on Sept. 26, 1973. Photo courtesy Richard Nixon Presidential Library and Museum, Yorba Linda, CA (WHPO box 137).

\section{https://journalism-history.org}


The literature on the Nixon administration, including the Watergate incident that brought about its demise, is extensive. ${ }^{12}$ Considerable material also deals specifically with the relationship between the news media and the Nixon administration, though much of it concerning broadcast journalism focuses on the CBS and NBC television networks. ${ }^{13}$ Some authors who have specifically examined Nixon's relationship with the press include those who worked for the president. Patrick Buchanan, the speechwriter most closely associated with Spiro Agnew's attacks on the media, has provided a firsthand account of the genesis and execution of the speeches. ${ }^{14}$ Journalists, too, have written extensively of their dealings with the Nixon White House. For example, journalist Jules Witcover has written two books on Agnew, which include extensive material on the vice president's relations with the press. Howard K. Smith's memoir sheds some light on his relationship with the Nixon White House, while Barbara Matusow's The Evening Stars and Marc Gunther's The House That Roone Built provide relevant details on ABC News during this period. ${ }^{15}$

This article proposes to fill a gap in the literature regarding the relationship between the Nixon administration and ABC News. While Nixon's relationship with the press has been well documented, his administration's interactions with $\mathrm{ABC}$ have not been. Drawing on primary sources from the Nixon Presidential Library, as well from other archival libraries, oral history transcripts, interviews, and FBI documents obtained through a Freedom of Information request, this article examines the administration's public and private efforts to both intimidate and flatter ABC. 16

Though Nixon's animus toward journalists can be traced to the McCarthy era, his hatred for newspeople was solidified following his losses in the 1960 presidential and 1962 California gubernatorial elections. The 1962 loss was particularly stinging, and Nixon felt the press had played a role in his defeat. In his concession speech, he lashed out at reporters, telling them that it was his "last news conference." Nixon's comments seemed out of character to Norman Chandler, the retired publisher of the Los Angeles Times and long-time Nixon supporter, who confided that the former vice president had "temporarily gone off his rocker." The only explanation, Chandler thought, was that "the poor fellow was in a horrible state of mind and completely exhausted." Nixon later wrote that the reporters "deserved" the tongue-lashing and that he was "glad" to have delivered it. ${ }^{17}$ But the concession speech, what Buchanan believed amounted to a "public political suicide," resulted in an ABC broadcast the Sunday night following the election called The Political Obituary of Richard M. Nixon. Ironically, it was Howard K. Smith who had produced and anchored the broadcast. Smith later remembered that Hagerty, the head of ABC News, sat at his elbow, "reading every line," Smith wrote. ${ }^{18}$ Coverage of the 1962 election scarred Nixon, leaving him with a particular dislike of television. It "seemed to confirm everything Nixon had said about a hostile and vindictive press," wrote Buchanan, who thought ABC's broadcast was intended to "spit on Nixon's grave."19

Spiro Agnew's rapid rise to national prominence similarly informed his attitude toward journalists. Barely six years after being elected to public office, Agnew became Nixon's surprising choice as running mate for the 1968 election. The Washington Post editorialized that it

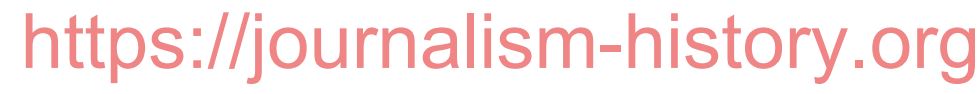


was "perhaps the most eccentric political appointment since the Roman emperor Caligula named his horse a consul."20 Agnew was elected governor of Maryland in 1966 By 1968 he had transformed his reputation from that of a liberal-leaning Republican executive into one embracing law-and-order conservatism, provoking black student protestors, and then condemning the Kerner Commision Report as "masochistic group guilt for white racism." His record provided the kind of political ambiguity that made him an attractive running mate for Nixon. ${ }^{21}$ Some political observers considered Agnew unprepared to make the transition from governor to vice presidential candidate. He made several gaffes on the campaign trail, including jokingly referring - not once but twice - to a reporter, in his presence, as a "fat Jap." Agnew intended the remark to be lighthearted and assumed it would be off the record. In another instance, he explained that he did not campaign in poor neighborhoods because, "If you've seen one slum, you've seen 'em all." 22 Though he joked that he was assigned "the task of insulting all groups equally," press coverage of the incidents left Agnew with a negative impression of the news media. "Look what happened to me," he told a friend later. "Six months ago I was a fairly popular and successful governor. But then they started treating me like I was the village idiot." 23

Agnew understood he served as a "lightning rod" to deflect negative coverage away from Nixon. ${ }^{24}$ Yet, he later admitted he was not in Nixon's inner circle - in fact, he felt distant from Nixon and disclosed that the two men had a troubled relationship. Nixon later "doubted" Agnew's intelligence, though he knew he was "good at talking tough," writes scholar Jon Marshall. ${ }^{25}$ Despite the negative press, Agnew, already popular with conservatives during the election campaign, gained even more popularity as vice president by "playing heavily to conservatives" and attacking the press. Agnew became so adept at going on the attack that Democratic presidential hopeful Eugene McCarthy nicknamed him "Nixon's Nixon." Conversely, Buchanan dubbed Agnew "the acknowledged spokesman of the Middle American, the Robespierre of the Great Silent Majority" and he urged Haldeman that be put "on the offensive."26 In time, conservatives would refer to Agnew as "Spiro, our hero," and bumper stickers would declare, "God Bless Spiro Agnew." Two Gallup polls taken after Nixon's first year in office indicated only evangelist Billy Graham and President Nixon surpassed Agnew as America's most-admired men. ${ }^{27}$

From the first days of the Nixon presidency, "it was clear there would be no peace" between journalists and the White House, and it was to be an adversarial relationship. Nixon believed the press was the enemy, something he stressed to speechwriter William Safire. "The press is the enemy," he repeatedly proclaimed while admonishing National Security Advisor Henry Kissinger and aide Alexander Haig to "write that on a blackboard 100 times." Nixon counseled his cabinet to "always remember" that the press was to be regarded as an "adversary." Nixon and his team, Pressman wrote, "never envisioned anything but an adversarial relationship."28 However, instead of accepting the role of victim of perceived media bias, the Nixon White House would use television itself "as a weapon." It had three strategies: it would use television to influence voters; it would mostly ignore questions from White House reporters yet carefully monitor their coverage; and its officials would verbally attack news organizations when their reports were deemed displeasing. ${ }^{29}$

\section{https://journalism-history.org}


Klein and Buchanan frequently called journalists to complain about what they thought was unfair coverage. In June 1969, Klein observed that ABC's Smith as "generally supportive" of Nixon's foreign policy and "sometimes negative" on domestic policy. However, Klein found some of ABC's reporting to be negative, noting, "I have talked with them about slanting." In particular, Klein was concerned about Smith's co-anchor, Frank Reynolds (Figure 2), noting, "I have worked on him through Jim Hagerty." He added, "All the network executives are aware of the fact that we are watching and they hear from me both ways." 30

However, by the fall of 1969, presidential aide Jeb Magruder became convinced that this way of dealing with the press and television networks amounted to what he called a "shot gun" approach that was "very unfruitful and wasteful of our time." Instead, Magruder suggested a series of more concentrated efforts, what he called a "rifle approach." In a document that would come to be known as the "shotgun versus rifle" memo, Magruder laid out other strategies that he believed would "have much more effect than a phone call from Herb Klein or Pat Buchanan." He proposed an FCC monitoring program that was to begin once former Republican National Committee chair Dean Burch was officially installed as FCC chair. Magruder also suggested that the networks be investigated for antitrust violations. "Even the possible threat of anti-trust action I think would be effective in changing their views," he wrote. ${ }^{31}$ Clearly, Magruder knew the vulnerabilities of network television. Broadcasters in the United States do not enjoy the same degree of First Amendment protection afforded to print journalists. Unlike newspapers, the federal government regulates broadcasters, and the FCC of the 1960s and 1970s regulated broadcasters much more stringently than they have since the presidency of Ronald Reagan. ${ }^{32}$

Nixon aide Lyn Nofziger expressed the White House stance: broadcasters were "government licensed media" that were expected to give the administration "fair treatment." Aide Ken Clawson put it in crasser terms: since broadcasters use the public airwaves, "we all have a piece of TV's ass and we're entitled to do something . . . if it offends us."33 Nixon agreed, believing, for example, that the threat of an antitrust suit would be more effective in bringing the networks to heel than an actual lawsuit: "If the threat of screwing them is going to help us more with their programming than doing it, then keep the threat," he told White House Counsel Charles Colson. "As far as screwing them is concerned," he added, "I'm very glad to do it."34

Nine months into office, just as aides were considering Magruder's proposals, Nixon faced a number of frustrations. Domestically, his nominee for the Supreme Court faced Congressional opposition. In Vietnam, the My Lai massacre was in the news. Meanwhile, antiwar protests continued to build strength, particularly the Vietnam Moratorium movement, which advocated that Americans take one day off each month - the fifteenth - to protest the war. In a cover story titled "Nixon in Trouble," Newsweek suggested, "thoughtful men" had "serious doubts about the President's essential ability to lead the nation." Meanwhile, David Broder wrote that Nixon's presidency was "in danger of being broken," as Johnson's was, prompting Buchanan to write a memo to the president encouraging him to defend his Vietnam policy. "You've got to stand up and we're going to have to explain to the country why we have to keep those kids over there

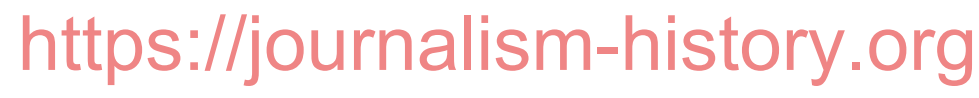


fighting and dying in Vietnam," he later remembered writing. ${ }^{35}$ Nixon agreed, deciding to respond with a major speech in which he aimed to reach out to average voters, those he called "a great silent majority," a moniker biographer Evan Thomas characterizes "a political masterstroke." 36

Nixon labored over the speech personally, spending days writing on yellow legal pads, "brooding over every comma." 37 While reserving sole authorship for himself, he gave his staff specific ideas on how to promote the speech, including garnering favorable comments on it from political leaders throughout the nation. Most importantly, Nixon wanted pressure applied to the news media: they were to be monitored and rebuked for negative coverage. Nixon did not want the networks handled in what he considered a "routine fashion" but rather with a "strike force," one for each network. 38

On Nov. 3, 1969, President Nixon delivered the nationally televised speech, which he considered at the time to be the most important speech of his career. His goal was to persuade Americans that he was serious about his campaign promise to end the war while simultaneously persuading the Vietminh and Vietcong that he was serious about defending an independent South Vietnam. Most memorably, he asked "the great silent majority of [his] fellow Americans" for their support. ${ }^{39}$ Although the speech deployed numerous "strategic misrepresentations," 40 scholar Karlyn Kohrs Campbell would later proclaim Nixon's speech "a persuasive masterpiece." 41 The speech appealed not only to Nixon's base but also to a far wider majority: polls indicated that 77 percent of the country supported him..$^{42}$ Nixon himself thought the speech could not have been more successful, later writing, "Very few speeches actually influence the course of history. The Nov. 3 speech was one of them." Nixon biographer Stephen Ambrose characterized the president's appraisal as "nonsense." Nevertheless, it was evident within weeks that the president had reached "a new majority." Nixon wanted his staff to promote the fact that he had written the speech himself and had made effective use of television. ${ }^{43}$

However, the president did not receive the praise he was hoping for from television newspeople, who filled the time between the speech and the next scheduled television program with commentary and analysis. Buchanan felt the networks' commentators were trying to "discredit" the president and instead should defer commentary until later, allowing viewers to "let it sink in what the President said. . . . Let them decide for themselves" 44 However, expectations for Nixon's speech had been raised so high that broadcast commentators analyzing the speech immediately afterward were critical that the president had not made news. "No new initiative, no new proposal, no new announcement of any new troop withdrawals," said ABC's Reynolds. ${ }^{45}$ As the discussions continued on all three networks, the president repeatedly called Haldeman, demanding to know what was being done for "all-out counterattack." $46 \mathrm{He}$ was most infuriated with Reynolds. The White House considered Reynolds "one of the most caustic, anti-Nixon reporters" of the 1968 presidential campaign and was said to have kept a dossier of his alleged misdeeds. ${ }^{47}$ Reynolds' commentary following the speech cemented Nixon's animus for him. Even more infuriating to Nixon was ABC News' decision to employ former New York governor Averell Harriman as an analyst. Harriman, a Democrat, had served as a negotiator with North

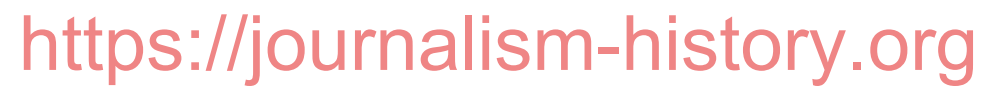


Vietnam on behalf of the Lyndon Johnson administration. To Nixon, Harriman's appearance on $\mathrm{ABC}$ was more proof that television journalists were going out of their way to make him look bad. 48

$<$ Insert Image 2_2>

Frank Reynolds was co-anchor of the ABC Evening News from 1968 to 1970. Photo Courtesy Georgetown University Library Booth Family Center for Special Collections, Frank Reynolds Papers 1, GTM-GAMMS64, box 11, folder 65 (CAmerican Broadcasting Companies, Inc. All rights reserved. Used with permission).

Nixon wanted to counterattack personally but realized he needed to appear calm for the sake of his image. As Joe McGinniss famously reported in The Selling of the President, Nixon's campaign had carefully reconstructed the candidate's media image from the brooding figure revealed in his "last news conference" and portrayed in Smith's "political obituary" into a more mature, thoughtful, and measured man-what became known as "a New Nixon." 49 In order to protect the president from reclaiming his reputation as a hatchet man, he would strike back through proxies. Dean Burch, newly confirmed as the chair of the FCC, made calls on Nov. 5 to the presidents of each of the three television networks, requesting transcripts of the comments that followed Nixon's speech. The same day, Klein reported that Burch's calls were effective. "All three network Presidents appeared to have been shaken up and concerned," Klein wrote. He added that Hagerty "was particularly delighted because he had had a major argument with the ABC news department." 50

Meanwhile, Haldeman instructed Buchanan, the president's speechwriter, to launch a campaign of protest letters and telegrams. Buchanan disagreed with this approach: "This is the time really to take on the networks directly," he remembered saying. ${ }^{51}$ Buchanan instead suggested that the White House respond to the networks' coverage with an attack of its own. In a memo he later regarded as "among the most consequential [he] ever wrote," Buchanan suggested the vice president should deliver "a major address" that he volunteered to write. The speech, he proposed, should call "for a national debate on the influence of a tiny handful of men elected by no one." Haldeman returned the memo to Buchanan with a notation in red ink: "Pat, Let's go! P is all for it." 52

At the time, Agnew was considered the perfect person to deliver the message, since he was "already at odds with reporters and considered to be the most expendable person" in the administration, as one historian has written. ${ }^{53}$ Although the White House later claimed Agnew was speaking for himself, going so far as to advance the fiction that neither Nixon nor the White House Press Office had even seen a copy of the speech in advance, Nixon himself was personally involved. ${ }^{54}$ After a few days of writing a draft, Buchanan was called to deliver it to the Oval Office for presidential review. As Nixon edited the draft, he "murmured," then turned to Buchanan and said, "This will tear the scab off those bastards." 55 Nine months into Nixon's first administration, a speech, and television news's reaction to it, served as a flashpoint between the

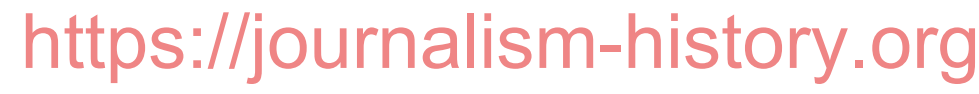


president and the press, causing, Klein later said, an "accidental start to all-out war in an arena where tensions had been smoldering for years." 56

Haldeman, noting that Nixon was "pleased and highly amused" by Buchanan's speech draft, approached Agnew on Nov. 10, 1969, one week after the president's speech. According to Haldeman's diary, the vice president said he thought such a speech would be "a bit abrasive," but he agreed to deliver it nonetheless. Later, Agnew claimed to have helped Buchanan write it, remembering, "The crafting and polishing of that speech was a labor of love." 57

As Agnew and Buchanan worked, the White House staff considered ways to get network television coverage of a speech that would slam those who worked in network television news, even briefly considering paying for television time. However, the White House first needed a venue in which Agnew could deliver the speech. The White House solicited an invitation for Agnew to deliver the speech at a Republican Party regional conference in Des Moines, Iowa. The conference was scheduled to begin on Nov. 14; organizers had planned only for conference registration on Nov. 13, but they agreed to add Agnew to the program that day, touching off "a scramble of activity" in order to prepare for it. 58 The television networks were sent advance notice an hour before it was to be given. ${ }^{59}$ Agnew personally informed Smith, through a letter, that he would say "some very strong things about television networks and their news presentations." However, he assured the ABC commentator that it was not personal: "I recognize that you were most generous in your recent comments about me and therefore I wanted you to know that this was in no way intended to imply an absence of appreciation on my part." Smith immediately responded to the advance copy Agnew had sent with the letter, writing, "I think it is fair criticism-indeed, I have made a little of it myself in print, in speeches and also on television itself." He added, "I predict you will be roundly criticized — and heeded."60

Though Klein claimed he was releasing an advance copy to the networks so he would not be accused of participating in a "sneak attack," the administration was essentially daring the networks to cover the speech. Klein was convinced the networks were afraid not to carry it. ${ }^{61}$ None of the networks had placed reporting or production crews in Des Moines. ABC had already broadcast its 6 p.m. and 6:30 p.m. versions of the Evening News but decided to preempt its 7 p.m. broadcast, intended for the West Coast, with the black-and-white feed of Des Moines educational television station. ${ }^{62}$ Upon learning that $\mathrm{ABC}$ was to carry the speech for its 7 p.m. feed, CBS and NBC followed suit. ${ }^{63}$ Buchanan thought the networks had just made "an insane decision," which caused him to become "mildly neverous." He decided to go swimming rather than watch the speech on television. ${ }^{64}$

As the vice president took to the podium at the Hotel Fort Des Moines, just after the dinner hour, he joked that it was "obvious from the cameras" that he did not come to speak about bans on artificial sweeteners or pesticides. 65 Then he got right to the point. Agnew accused the television networks of bias and pointed to Nixon's recent "silent majority" speech as the latest example. The vice president complained that after the president delivered a speech he had spent weeks preparing, his words were immediately subjected to "instant analysis" and "querulous criticism."

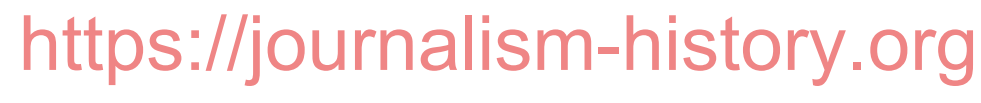


It was, according to Agnew, "obvious" that the commentators" minds were "made up in advance" of Nixon's speech. Although he did not mention ABC News by name, Agnew criticized the network's decision to "guarantee in advance that the president's plea for national unity would be challenged" after it "trotted out former Democratic governor Averell Harriman for the occasion," who then "recited perfectly" the Democratic Party's criticisms of the president. Agnew charged that even the content of the nightly network newscasts, seen by millions of Americans, was determined by "a small group of men, numbering perhaps no more than a dozen anchormen, commentators, and executive producers" who can "create national issues overnight" and "elevate men from obscurity to national prominence within a week." According to Agnew, a "raised eyebrow, an inflection of the voice, a caustic remark dropped in the middle of a broadcast can raise doubts in a million minds about the veracity of a public official or the wisdom of a government policy." Agnew emphasized that he was not calling for government censorship — or any other kind of censorship — but he told his audience that they should be concerned about a "tiny, enclosed fraternity of privileged men elected by no one" who control a "virtual monopoly of a whole medium of communication." Even as he ascribed such power to the networks, the vice president claimed that even he could not be assured of getting his message out: "Whether what I've said to you tonight will be heard and seen at all by the nation is not my decision. It's not your decision. It's their decision." Perhaps it was time, Agnew suggested, that this "small band" was "made more responsive to the views of the nation and more responsible to the people they serve." Agnew then encouraged his audience and Americans everywhere to "register their complaints" with television networks and local television stations, by telephone and by mail, telling them that Americans "want their news straight and objective." 66

The speech was front-page news, above the fold, in the following morning's New York Times, which reported, "thousands of Americans immediately responded to the Vice President's invitation" to register their complaints with the networks. ${ }^{67}$ Two days after the speech, the Times reported that Burch, the FCC chair, publicly sided with the vice president. ${ }^{68}$ Agnew's comments were "thoughtful, provocative and deserve careful consideration by the industry and the public," Burch said. Furthermore, Burch acknowledged that he had requested, from all three networks, transcripts of comments made following Nixon's speech on Nov. 3.69 Agnew denied he was advocating censorship, as did the White House - speechwriter James Keogh claimed that nobody in the administration "was even thinking" about it, and, in any event, they "knew that it was both practically and politically impossible." 70 Nevertheless, the damage had been done: the television networks knew they had been put on notice by the government, which had the power to grantand revoke - broadcast licenses. Even if the FCC did not become involved, network executives heard an implied threat that, at a minimum, could induce their journalists to practice selfcensorship. ${ }^{71}$

The evening following Agnew's speech, ABC Evening News with Frank Reynolds and Howard $K$. Smith aired, in the place of its regular slot for commentary, reactions from Leonard Goldenson, the head of ABC, and from his counterparts at CBS and NBC. Each expressed deep concern. ${ }^{72}$ However, on Nov. 18, Smith commented on the ABC Evening News that he agreed with much of Agnew's speech and had even made many of the same comments himself. ${ }^{73}$

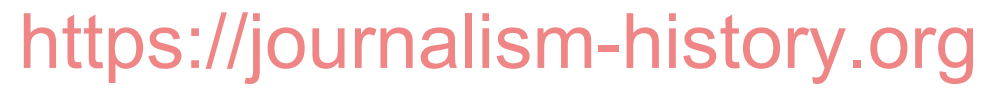


Smith's co-anchor weighed in three days later with a commentary of his own, asserting that Agnew did not want "independent analysis, but collaboration." The vice president, Reynolds continued, "confuses commentators with cheerleaders." Reynolds reassured his viewers that, contrary to Agnew's charges, "the position of a commentator's eyebrow will not determine their position on really important matters." 74

The networks were unhappy with Agnew, but the White House was elated. Haldeman noted that Agnew had developed into "a good property," adding, "Keep building him." 75 Within a week of the Des Moines speech, at least three national magazines elected to profile the men who the vice president had said were largely responsible for selecting what news Americans watched on television. Women's Wear Daily dubbed the news executives the "Dirty Dozen," while Time magazine referred to them as the "Unelected Elite" and Newsweek called them "Faceless Men."76 Nevertheless, there were some rumblings that a few moderate Republicans were nervous about Agnew's attacks. Klein told an audience in New York that he did not expect the vice president would continue the attacks, adding that Agnew was "hopeful" that criticism of his speech would recede from hyperbole to a "calm, healthy discussion" of "anti-Nixon bias in the media." 77 Agnew reportedly had heard that the president wanted him to ease up. However, Colson noted that Haldeman had told the vice president that Nixon wanted him to "go all the way" in his attacks. ${ }^{78}$

One week after his Des Moines speech, Agnew was scheduled to speak again, this time in Montgomery, Alabama. Amid the conflicting messages, there appears to have been some internal debate over just how harsh the vice president's next speech should be, with multiple proposed versions emerging. Both Klein and White House Press Secretary Ronald Ziegler expressed concerns about the proposed speech text, suggesting a less strident version be presented. ${ }^{79}$ However, when Agnew took the podium in Montgomery, he read the harsher of the speech versions, thus expanding the administration's attack on the news media to include newspapers. ${ }^{80}$ Responding for $\mathrm{ABC}$, Goldenson had Hagerty call in his statement to Klein's assistant, within minutes of the conclusion of Agnew's address, suggesting, "the ultimate judges" of the network newscasts "will be the viewing public." Nevertheless, Goldenson viewed the vice president's remarks as "an attempt to intimidate and discredit" television news. ${ }^{81}$

Back in the White House, Buchanan thought Agnew's pair of speeches was a success, but he worried they risked being too successful. Buchanan believed that a "temporary armistice" would benefit the administration more than it would the networks. The White House had clearly unnerved the networks and rallied support in the South and throughout the country. "Why waste it now piling up our poll results?" Buchanan argued. Why not, he reasoned, save it for later, when it might be needed? Instead, Buchanan suggested that Agnew "move on to other issues, where he [could] be strong and positive." Meanwhile, "the lessons learned" in November 1969, Buchanan wrote, "should not be forgotten in 1970 or 1972." Nixon noted his agreement in a handwritten note in the margin of Buchanan's memo. ${ }^{82}$ Nevertheless, the vice president continued with the media critiques that had given him increased relevance. ${ }^{83}$

\section{https://journalism-history.org}


Publicly, ABC put on a brave face publicly. Av Westin, executive producer of the $A B C$ Evening News, claimed there was "absolutely no sense of fear" at ABC, "either on the part of those on the operating level or on the part of management." In a radio interview, Westin reported that Lower had spoken with him only once. He said, "Just keep on doing what you're doing." 84 However, by Nov. 20, the network had received approximately 23,000 messages, of which some 7,000 had been read. Hagerty advised Goldenson, "if the present ratio of 9 to 1 in favor of Vice President Agnew continues, it will mean that 20,700 favor Mr. Agnew and 2,300 oppose him." 85

Perhaps alarmed by this response, perhaps only wanting to make sure, as he said later said, that he and his network journalists "weren't telling [themselves] what [they] wanted to hear," Lower commissioned a content analysis of his newscast. ${ }^{86} \mathrm{~A}$ frequent public speaker, the ABC News president wanted to have some hard numbers in hand as he went out to defend his network's journalism. So he turned to Irving Fang, a University of Minnesota professor and journalism $\mathrm{PhD}$ who had recently worked for $\mathrm{ABC}$ News as a writer and researcher, to design and conduct the analysis. Though Fang did his best to be rigorous and fair, selecting a seven-member team representing both liberal and conservative viewpoints, the study was rushed. Over the course of eight days, the team viewed and analyzed ninety-five hours and three minutes of $A B C$ Evening News from the past year that had pertained to political news, the Vietnam War, and the Nixon administration. Fang told Lower his methodology would "never have withstood the test of academic rigor" for scholarly publication, but it was reliable enough "for a private study," concluding, "It was the best I could do." 87

In December, Lower addressed law students at Columbia University, where he took the opportunity to unveil the results of Fang's content analysis. Overall, the study suggested that ABC News was balanced in its coverage. Among other things, it indicated that stories that were "likely to be pleasing to a supporter of the administration" totaled 12 hours, 39 minutes. Stories that were likely to displease supporters of the administration totaled 10 hours, 18 minutes. Stories deemed neutral in the study totaled 8 hours and 18 minutes. The survey also categorized commentaries presented by ABC's anchors, finding those tending to support the Nixon administration totaled 1 hour, 24 minutes; commentary tending to be critical added up to 58 minutes, while those characterized by the researchers as neutral totaled 1 hour, 46. Lower wondered aloud why, then, with coverage apparently so evenhanded, television journalists "suffer the slings and arrows of bias charges." Though he understood that many viewers were offended by bad news, he asserted that television should not take the blame for what is perceived as bad news any more than it should be credited for what might be perceived as good news. "None of it is our making," he said. Lower told the law students that all the networks covered Agnew's speech because of the newsworthiness of a high government official offering "even a hint of bureaucratic interference," which cast "a grave shadow" upon the credibility of the country's news media. That all three networks covered Agnew's speech was not, Lower said, the decision of a "small band of network executives working together." Rather, he said, it was the result of "three independent judgments by three men experienced in journalism." Furthermore, the networks compete, he said, "vigorously." 88

\section{https://journalism-history.org}


A week later, Agnew responded to Lower's remarks in a letter to Hagerty. ${ }^{99}$ Agnew wrote that he took "grave exception to [Lower's] apparent feeling that no federal official should criticize a federally licensed medium." Agnew argued, "the mere fact that public interest dictates a license requirement provides adequate reason for open comment on whether or not the medium is serving its purpose." Agnew believed he had not only "a right" but also an "obligation" to criticize network television. ${ }^{90}$

Despite ostensibly representing $A B C$ 's interests as its executive vice president for corporate relations, Hagerty told Agnew he agreed: "Unlike some of my associates in the television industry, I believe that you have every right — as Vice President and as an individual — to criticize the industry where you believe it is improperly presenting and analyzing the news of our times." Hagerty added that he believed that "the overwhelming majority of citizens of our land support and applaud you for doing so." Hagerty backed up the claim with ABC's latest letter count. By the first week of January, the network had received approximately 30,400 pieces of correspondence: "letters, postcards, and telegrams." Hagerty advised Agnew that the mail ran "7 to 1" in the vice president's favor. Agnew responded later that month, calling Hagerty's mail count "helpful," adding that he hoped it was "becoming apparent to the overreacters [sic] among the media men that [he was] not advocating censorship or a grand design for bringing down freedom of the press." Agnew added that, having made his point, he was "content to let the legitimacy of the complaint bring about the needed reform." 91

As Hagerty was corresponding with Agnew, he was also lending support to Ziegler. A negative story in the press that Hagerty thought was unfair to Ziegler prompted Hagerty to write to Nixon's press secretary. "As both you and I know, the job of Press Secretary to the President of the United States is never an easy one," he wrote. Moreover, "it is also a job that creates envy and jealousy among certain members of the news media - the individuals that you and I know only too well who conceitedly think they know all the answers to all the problems and issues that confront a President." While allowing that not all journalists fall into such a category, Hagerty asserted there were some who not only "pride themselves as self-styled liberals" but are "actually reactionaries who cannot accept or understand anything that does not fall into their own preconceived beliefs, particularly the intelligent use of evolving communication techniques by a President or Press Secretary." 92

Another of Hagerty's correspondents was FBI Director J. Edgar Hoover. Between the years 1965 and 1974, ABC had produced and aired a successful television drama about the bureau, titled The FBI. It was done with Hoover's cooperation and approval; Hoover reportedly even had final approval rights for scripts and casting. The FBI director claimed he had received hundreds of proposals from producers to do such a show but that he finally agreed to such a television partnership when it was proposed by two people he could trust-Hagerty and movie mogul Jack Warner. ${ }^{93}$ Hoover wrote to Goldenson in January 1970 to praise ABC for airing "factually based news" that reflected "truth rather than distortion." For this, as well as for the FBI's partnership with $\mathrm{ABC}$ in airing The FBI, Hoover credited "our good friend Jim Hagerty." 94

\section{https://journalism-history.org}


Weeks after the Nixon and Agnew speeches, Haldeman tasked Klein and Ziegler with evaluating network commentators based on whether they were "with" the Nixon administration, "against" it, or "generally objective." As an example, Haldeman wrote, "Howard K. Smith would be listed now as generally with us . . . Frank Reynolds as general against." Haldeman directed that the analysis "should be done in the next few days, since the President is anxiously awaiting it."95 One of the items Nixon was considering was whether to reward Smith with an exclusive interview with Agnew. ${ }^{96}$ Klein responded by classifying Smith as "particularly good on Vietnam, where he is tough-minded, and on international affairs in general." On the other hand, he found Reynolds was "sometimes snide" and remarked, "It can be said clearly that he is not a Nixon supporter." However, he noted, "There are growing pressures at ABC to keep him objective."97 Ziegler also had attempted to obtain more background on journalists, but worried about the potential disclosure of such an investigation, particularly "in the light of the Vice President's recent addresses." 98 Ultimately, Smith conducted the interview with the vice president; however, it was put on hold until February 1970, "so that it would not look like Smith had sold out."99

In January 1970, following the president's State of the Union address, Klein reported to Nixon on network reaction, writing that Smith concluded ABC's coverage by saying he "personally agreed with much of what the President had said."100 Weeks later, an article written by conservative media critic Edith Efron, published in $T V$ Guide, pleased the White House. It featured Howard K. Smith's criticisms of television news. Although not intentional, Smith said, television journalists were biased. Networks, he said, "are almost exclusively staffed by liberals." 101 Delighted with the article, Nixon requested that copies of it be circulated throughout the government. Smith's comments in the article were also highlighted in a political newsletter. ${ }^{102}$ Increasingly, ABC was becoming the administration's favorite network news organization.

In summer 1970, Colson was assigned to meet with the heads of each of the television networks. Reporting to Haldeman in an "Eyes Only, Please" memo that he found executives "terribly nervous" and "apprehensive," Colson wrote that the network heads were "startled by how thoroughly [the administration was] doing [its] homework" and monitoring its newscasts. So engaged were network executives that Colson claimed he had to initiate ending each of the meetings. "The networks badly want to have these kinds of discussions," he wrote. The meetings had been effective, he concluded, in letting the networks know the White House was determined to prevent the networks from interfering "with the President's ability to communicate" with the public. ${ }^{103}$ His visit with Leonard Goldenson and his people gave him the impression that ABC would be receptive to the administration's demands - "anything we want," Colson claimed, adding, "Hagerty said in Goldenson's presence that ABC is "with us." 104 In September, Nixon sent positive reinforcement to $\mathrm{ABC}$ via a "Dear Leonard" letter in which he expressed appreciation for the network's news division "striving for fairness, making clear distinctions between news and commentary and reporting the good as well as the bad." Goldenson responded that the letter gave

"additional incentive to strive for fair and impartial presentation" of the news. 105

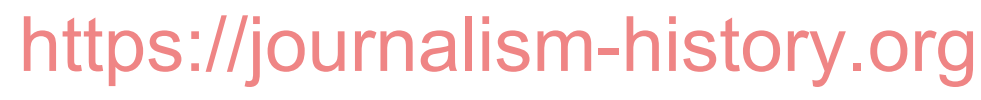


Despite the administration's simpatico relationship with ABC's corporate leaders and with Howard K. Smith, the $A B C$ Evening News maintained a certain editorial balance. Not only did ABC have Lower's content analysis to back up the claim-after the initial rushed study in November 1969, Lower contracted Fang to conduct one annually for the next four years-but viewers could see the difference for themselves. Beyond the visually obvious (Smith broadcasting from Washington while Reynolds anchored from New York), their on-air commentaries differed. Many, if not most, of Smith's commentaries-particularly those on the Vietnam War - pleased the White House. Smith “editorialized so frequently on behalf of Nixon's policies that $\mathrm{ABC}$ acquired a new nickname: "The Administration Broadcasting Company."'106 ABC's Bill Sheehan dismissed "the charge that ABC was the "Nixon network" as "ridiculous." 107 Even so, viewers were likely unaware at the time that Smith would speak often with Nixon, sometimes over the phone, other times in the White House with his wife. "I greeted the opportunity to have contact with the president," Smith said.108 "Perhaps the main reason our relationship prospered was that I favored much of what Nixon was doing," Smith later wrote. 109 In January 1971, Colson met Smith for lunch and discussed an interview Nixon had given to network correspondents earlier in the week, with both of them "lavishing praise on the President." 110 Reynolds, on the other hand, continued to rankle the administration. When Agnew criticized the media for giving protestors attention, Reynolds editorialized that what the vice president meant was that "the real villains are the familiar ones-television and newspaperswhich according to Mr. Agnew, give the kooks and demagogues respectability." 111

Meanwhile, ABC's nightly newscast continued to improve, even as it struggled financially (a failed merger attempt with ITT forced the network to slash its 1968 news division budget by 25 percent). ${ }^{112}$ Its biggest problem was that it could not convince all ABC-affiliated television stations to carry the newscast, so it remained mired in third place. The situation was so dire that when Westin was hired as executive producer of the Evening News in March 1969, he was shocked to learn that the ABC affiliates board was considering pressuring the network into scrapping the newscast altogether in favor of a syndication service. Westin later remembered feeling as though working at $\mathrm{ABC}$ under such circumstances was like "going down the highway at seventy-five miles an hour and changing the hubcaps."113 In mid- 1970, ABC seized an opportunity to hire CBS 60 Minutes correspondent Harry Reasoner, which then created the need to decide which of its two current anchors to replace-Howard K. Smith or Frank Reynolds. Ostensibly believing that Reynolds and Reasoner brought similar skills to the broadcast, ABC decided to keep Smith and remove Reynolds. As vice president of ABC News, and the person directly responsible for the Evening News, Sheehan was tasked with breaking the news to Reynolds. Sheehan knew that Reynolds had "just come off doing an election night in which he was magnificent . . . a moment when he was operating at his best." He later realized that Reynolds thought he was being called in for commendation, "which he deserved," Sheehan said. Instead, Reynolds was told he was being taken off the broadcast and reassigned. Sheehan thought Reynolds looked like he was having a heart attack. Breaking the news to Reynolds, Sheehan said, made it the worst day of his career. ${ }^{114}$ Lower later said he "didn't think there was any reason" to replace Reynolds, that he was doing well and that, given just a bit more time, the Reynolds-Smith team would see increased ratings. But Lower's superiors pointed out that

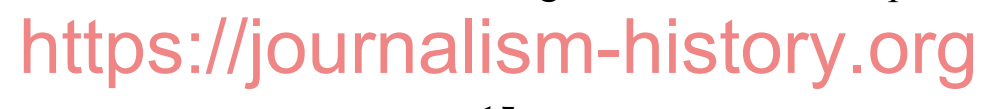


audience research weighed in Reasoner's direction. "The facts were against me. So we took him," Lower said.115 Reynolds believed his commentaries resulted in pressure from the Nixon White House. "I paid a price for stating my views," he later said. Though allowing there were "other factors," he believed his criticism of the Nixon administration was "definitely a factor," noting "Howard K. Smith was retained and he endorsed Agnew’s views."

ABC allowed Reynolds to continue co-anchoring the broadcast until Reasoner's arrival. On Nov. 19 , he offered commentary in response to Hoover's recent remarks about former attorney general Ramsey Clark, who had just published a book. The Washington Post reported that Hoover called Clark "the worst Attorney General he had encountered in 45 years as director" of the FBI. Hoover said his former boss was "like a jellyfish . . . a softie" and "worse than Bobby Kennedy."117 Reynolds's on-air reaction was that Hoover, who did not "welcome criticism," was "the real 'Untouchable' in Washington," adding that the famous prohibitionist Eliot Ness "would not have dared pulled the plug in the Hoover bathtub had it been found full of gin." Hoover "has been a good cop and a useful public servant," Reynolds concluded. "He is not, however, above reproach."118

Reynolds had turned a clever phrase by calling Hoover an "untouchable," but it hit a nerve: Ness had called his Chicago prohibition agents "The Untouchables"-and Hoover saw Ness as a rival. ${ }^{119}$ According to FBI documents, Hoover was so angry that he put out word that he was withdrawing the FBI's support of ABC's The FBI. ${ }^{120}$ Subsequently, Martin Pompadur, the ABC executive responsible for the program, got on the phone to forward his apologies to Hoover. An FBI report stated, Pompadur "advised that he fully shares the Director's feeling concerning this matter and he deeply regrets the concern caused . . . by Reynolds' viciousness and unwarranted activity." Furthermore, Pompadur advised the FBI "Reynolds had been a continuing problem for ABC insofar as the content of and the manner in which he handles his broadcasts." As a result, "he [was] being dropped from the ABC news staff as of December 7th and [was] being replaced by Harry Reasoner."121

Upon learning of the incident, Hagerty immediately called the FBI, requesting a meeting with Hoover. ${ }^{122}$ The next morning, Hagerty flew to Washington to attempt to assuage Hoover. Hagerty reminded his old friend that "while his current responsibilities involve[d] Corporate Affairs, he [was] himself essentially a newsman, and that he [tried] when he [was] able, to oversee the activities of the ABC News Department." Reasoner was scheduled to replace Reynolds in two weeks, Hagerty told Hoover. However, "if they could, they would get rid of Reynolds entirely." According to FBI notes of the meeting, Hagerty reportedly "begged multiple times" to keep The FBI on the air. His entreaties assuaged Hoover; the director said that as long as Reynolds was off the broadcast, the FBI would "approve participation of the Bureau in the telecasting of 'The FBI' for a seventh season." Having settled that, Hoover and Hagerty discussed "the fine job being done by Vice President Agnew."123

"This is my last program as anchorman for the ABC Evening News," Reynolds said on the Dec. 4, 1970, broadcast. "On Monday, Harry Reasoner, whom I respect personally and professionally,

\section{https://journalism-history.org}


takes over. I wish him well." However, Reynolds was not going without complaint: "I'm not going to suggest that I'm completely happy about what has happened to me. . . I don't like it one bit, and see no reason to pretend that I do."124 Smith thought the change was "a big mistake." He thought Reynolds "was the perfect anchorman," while Reasoner ended up being "difficult" to work with. Smith was mystified that "somehow, they didn't like" Reynolds. "They didn't think he was doing a good enough job," Smith said. Years later, Smith still did not think Reynolds was fired because of politics; it was because "Reasoner was famous and they thought he would raise ratings. He didn't."'125

In fact, $\mathrm{ABC}$ 's ratings did go up during Reasoner's first months, in part, because the network convinced more affiliated television stations to carry the newscast. ABC sent Reasoner to an affiliates meeting in Los Angeles. As Reasoner later remembered it, "Nobody had told me to be tactful, so I wasn't." Reasoner told station managers that, with all the social problems in the country, "any network affiliate which did not carry that network's evening news was a disgrace to the broadcast industry." 126 As ABC increased the number of stations carrying the newscast, Buchanan recognized the new Smith-Reasoner match as the administration's "best hope for a fair shake." He advised granting ABC the "best leaks" and a "major special."127 Though happy that Reynolds was no longer offering commentary, administration officials did not always find themselves necessarily happier with Reasoner. In May 1972, a Reasoner commentary on Vietnam infuriated the White House, prompting an aide to call Reasoner directly to complain. ${ }^{128}$

The new broadcast's growth was noted when ABC's top executives came to the White House for an off-the-record meeting with President Nixon. According to Colson's account of the meeting, ABC's representatives were surprised when Nixon noted that ABC's Evening News had increased its Nielsen ratings and that "he expected — with a team like Reasoner and Smith — this would continue." The president expressed his satisfaction with the new anchor team, opining that it was "balanced." Nixon then offered to give a one-on-one television interview to ABC, with Smith as the interviewer. ${ }^{129}$

In spring of 1971, Nixon hired ABC News correspondent John Scali as a special consultant for foreign affairs and communications. ${ }^{130}$ It was, perhaps, a surprising hire. In November 1969, when Ziegler was tasked with rating the level of individual reporters' sympathy for Nixon, the press secretary had characterized Scali as "generally against" the administration. ${ }^{131}$ President Nixon wrote to Goldenson to express appreciation for allowing the administration to "have the benefit of his many talents," adding, "There is no doubt in my mind that he will make a vital contribution to our efforts and that he will be even more valuable to you on his eventual return to ABC."'132

Scali was no fresh-faced cub reporter. He was a key conduit in defusing the October 1962 Cuban missile crisis, a veteran reporter, and an expert in international relations. However, it is unlikely he knew that the president for whom he now worked was, at the time, vowing to "get" his enemies: "We'll get them on the ground where we want them. And we'll stick our heels in, step on them hard and twist," the president reportedly told Colson and Kissinger. ${ }^{133}$

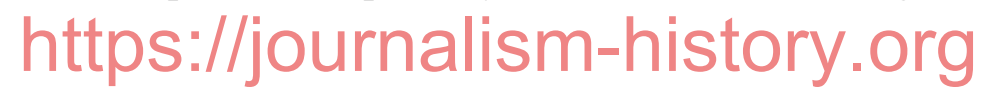


It did not take long for Scali to find his new hat to be a tight fit as he transitioned from political enemy, as the White House saw him, to White House aide. During Scali's first week in the White House, Colson presented him with a critically annotated log of the networks' coverage of the recently discovered secret bombing of Laos. ${ }^{134}$ Scali responded that he was "dumbfounded" and "astonished" that Colson was accusing ABC of an anti-Nixon bias. Furthermore, Scali doubted the accuracy of the media logs, particularly since he found some included many of his own stories, which he told Colson "were not anti-Administration in intent or content." Scali also reminded Colson of the content analyses that Lower had ordered: "ABC has kept very careful records for the past two years" and "has data to show that it featured more pro-Administration than anti-administration" stories. ${ }^{135}$ The following day Scali wrote to Colson again, urging that journalists were more likely to believe the White House if it openly admitted errors. He defended his former employer, vouching for the reporters whose stories Colson had found objectionable: "The men are damn good, honest reporters who do not needle copy for headline purposes." His former ABC colleagues occasionally made mistakes, he wrote, "but their batting average [was] remarkably high."136

Scali knew that some reporters and commentators had a liberal bias, but he did not believe journalists were conspiring against the Nixon administration. Now that he was inside the beast, he was learning firsthand of the depth of animosity his new colleagues had for his old ones. In a memorandum for the president, Scali wrote that he had "become increasingly disturbed in the past few days in private conversations with newsmen who suspect the Administration is orchestrating a stepped-up campaign of attack against the news media." Scali told Nixon he was particularly distressed that the accusations were "being voiced by reporters [he considered] responsible and fair-minded, not by the usual liberal news critics who [were] quick to believe the worst about the Administration."137

Scali discovered that Colson frequently perceived slights in even routine coverage. For example, in one news summary Colson wrote that he was "thunderstruck" by Reasoner's interpretation of economic indicators. Later, a summary of reporting on Vietnam peace talks quoted ABC's Lou Cioffi as saying that the North Vietnamese were "ready and anxious to reach a settlement." Reading the summary, Nixon noted in the margin, "John Scali-this guy is a commie, pink Bastard." Yet another notation was transcribed on White House letterhead and sent to Scali: "This guy is an enemy, a no good bastard, can't ABC stop him?"138

Negative press coverage, Buchanan wrote, acted on Nixon like "a soldier who had been wounded badly in a war long ago and, when the weather turned, the pain would return." 139 Nixon wrote to Haldeman, "I cannot emphasize too strongly . . . the discrediting of the press must be our major objective over the next few months." 140 Scali disagreed. Attacking the news media was contrary to his professional orientation and, he believed, politically counterproductive. On June 27 , just ten days after the Watergate break-in, Scali drafted a memo in which the president would disavow running an anti-press campaign. Scali had forwarded the proposed memo to Haldeman on July 21, indicating that he had hoped the president would send it. ${ }^{141}$ Although the June 27

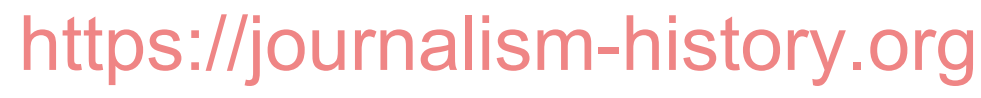


memo remained dormant, Nixon had reportedly changed his mind about the wisdom of carrying on with the war on the media. Haldeman told Scali in July that the president had "discussed at length with the Vice President the need to stop the shotgun attacks against the press" and had given the "signal very loud and very clear that the Vice President is going to follow the president's wishes in this area." 142 Subsequently, Agnew proposed to a newspaper publishers' convention that both the administration and the press put aside its war. ${ }^{143}$ The Agnew speech delighted Scali, who told Haldeman he regarded it as "in effect a declaration of truce in the war against the press." 144 Despite his efforts, there is no evidence to suggest Scali played a significant role in influencing the White House to call a truce.

On Oct. 10, 1973, five years into the Nixon presidency, and in the midst of the Watergate scandal, Agnew resigned, pleading no contest to tax evasion charges, after it was discovered he had been taking envelopes of cash bribes since his time as a Baltimore County executive, even during his tenure as Maryland governor and while in the White House. Since February 1973, Agnew had been fighting corruption charges, calling them "damned lies." 145 Less than two weeks later, ABC's Smith, Nixon's favorite commentator, called for the president's resignation. "For the good of the country, he needed to fight his battle for his reputation on his own time," Smith later wrote, claiming, "nothing quite so forthright had been said on television."146

That Smith was the first commentator to call for Nixon's resignation is but one of the unique aspects of ABC's role in Nixon's war on television. Smith, with Hagerty at his elbow, was the one who had wounded Nixon with the network's 1962 "political obituary" broadcast, but he ended up being the president's favorite television journalist. Equally significant was Hagerty's work behind the scenes, which seemed at times more in sympathy with the Nixon White House than with the network that employed him. In January 1971, Hagerty reportedly threatened to come out of the shadows to denounce his own network. Magruder claimed that if ABC's perceived bias was not corrected, Hagerty would "publicly denounce that type of activity by his own employer." 147 Meanwhile, Reynolds firmly believed he was removed for political reasons. Although he later expressed "regret" that he had not criticized the administration "in a better, perhaps mature way," he realized he had "made enemies in the White House by refusing to function as a cheerleader," thereby giving ABC the opportunity to replace him with Reasoner, who he regarded as a "very popular and thoroughly professional reporter." 148 Sheehan, Smith, and Lower all denied that Reynolds was removed due to political pressure. Nevertheless, it is possible that their superiors were motivated by politics. ABC executives Hagerty and Pompadur were, when Reynolds angered Hoover, all too willing to admit as much. "It was not a very proud time in the history of television," Reynolds later said. ${ }^{149}$

Agnewism not only was good politics but also was arguably successful in affecting network coverage. Jay Edward Epstein claimed that when Westin was hired as executive producer of $A B C$ Evening News in 1969, "he was given a mandate" to make the broadcast "more evenly balanced politically." According to Epstein, $\mathrm{ABC}$ may have been motivated to do so by economic imperative-specifically, getting more ABC affiliates to carry the newscast. ${ }^{150}$ By 1974, Buchanan, architect of Agnew's attacks on television, saw progress, claiming the networks

\section{https://journalism-history.org}


understood that the public considered them to be biased.151 Although Lower, Sheehan, and Westin all declared ABC's editorial independence, the Los Angeles Times suggested, "the word had gotten out" that "ABC had agreed to modify its supposedly anti-Nixon stance."152 Agnewism also had a "permanently dampening effect" on television analysis and resulted in both network and local television working to include "good news stories, resulting in softer newscasts." 153 In using Agnew to fight his war with television, Nixon tapped into a resentment between rural and suburban areas in the 1960 s that, along with antipathy toward a perceived liberal media, have not only persisted but have been amplified in American political discourse during the Trump administration. Though their media environments could not have been more different, both presidents experienced a love-hate relationship with the medium of television. For the thirtyseventh president, it was a "mutual hostility" that had been going on "ever since Mr. Nixon and a television camera first set eyes on one another."154

About the author: Dale L. Cressman, an associate professor in the School of Communications at Brigham Young University, gratefully acknowledges the school's Wendell J. Ashton Endowed Professorship, which funded this research, as well as the assistance and generosity of numerous activists and colleagues. Before earning his $\mathrm{PhD}$ at the University of Utah, he worked as a television news producer.

Contact: Dale L. Cressman, cressman@byu.edu, School of Communications, Brigham Young University

Disclosure Statement: No potential conflict of interest was reported by the author

Funding: This work was supported by the Brigham Young University School of Communications Ashton Professorship.

\section{Notes}

1 Spiro T. Agnew, "Speech to Mid-West Regional GOP Committee meeting," Nov. 13, 1969, Des Moines, IA, box 128, series III, Spiro T. Agnew Papers, Special Collections, University of Maryland Libraries (henceforth cited as Agnew Papers); Susan Buzenberg and Bill Buzenberg, Salant, CBS, and the Battle for the Soul of Broadcast Journalism: The Memoirs of Richard S. Salant (New York: Basic Books, 1999), 76; Michael Socolow, "Agnew Speeches Sparked Move Toward Soft News," Bangor Daily News, Nov. 13, 2009; and Jill Lepore, "Does Journalism Have a Future?" The New Yorker, Jan. 21, 2019.

2 William Safire, Before the Fall: An Inside View of the Pre-Watergate White House (Garden City, NY: Doubleday, 1975), 343 and 357; Herbert Klein, Making It Perfectly Clear: An Inside Account of Nixon's Love-Hate Relationship with the Press (New York: Doubleday, 1980), 166; and David Halberstam, The Powers That Be (New York: Alfred A. Knopf, 1979), 597.

\section{https://journalism-history.org}


3 Matthew Pressman, On Press: The Liberal Values That Shaped the News (Boston, MA: Harvard Press, 2018), 185.

${ }^{4}$ Communications Act of 1934, 47 U.S.C. $§ 151$ (1934).

5 “How Much Management of the News?" Newsweek, April 8, 1963, 59.

${ }^{6}$ Lyle Johnston, Good Night, Chet: A Biography of Chet Huntley (Jefferson, NC: McFarland, 2003), 105.

7 Jon Marshall, Watergate's Legacy and the Press: The Investigative Impulse (Evanston, IL: Northwestern University Press, 2011), 59.

8 Robert J. Donovan and Ray Scherer, Unsilent Revolution: Television News and American Public Life, 1948-1991 (Cambridge, MA: University of Cambridge, 1992), 118.

9 Michael M. Grynbaum, "Trump Renews Pledge to 'Take a Strong Look' at Libel Laws," New York Times, Jan. 10, 2018. See also Marvin Kalb, Enemy of the People: Trump's War on the Press, the New McCarthyism, and the Threat to American Democracy (Washington, DC: Brookings Institution, 2018).

10 Edward Bliss, Now the News: The Story of Broadcast Journalism (New York: Columbia University Press, 1991), 224; Robert Goldberg and Gerald Jay Goldberg, Anchors: Brokaw, Jennings, Rather, and the Evening News (New York: Birch Lane Press, 1990), 131.

11 Details of Hagerty's 1961 appointment are found in box 42, folder 8, Leonard H. Goldenson Papers, University of Southern California Cinematic Arts Library, Los Angeles. For Hagerty's work as Eisenhower's press secretary, see Craig Allen, Eisenhower and the Mass Media: Peace, Prosperity, and Prime-Time TV (Chapel Hill, NC: University of North Carolina Press, 1993); Elizabeth A. Nissen, "James C. Hagerty: Public Relations Genius," Public Relations Review 1, 3 (1975): 37-46; Gordon A. Moon, "James Campbell Hagerty's Eight Years in the White House" (master's thesis, University of Wisconsin-Madison, 1962).

12 Among notable works are Stephen Ambrose, Nixon: The Triumph of a Politician, 1962-1972 (New York: Simon and Schuster, 1989); Douglas Brinkley and Luke Nichter, The Nixon Tapes: 1971-1972 (New York: Houghton-Mifflin Harcourt, 2014); Rick Perlstein, Nixonland: The Rise of a President and the Fracturing of America (New York: Scribner, 2009); David Greenberg, Nixon's Shadow: The History of an Image (New York: W. W. Norton, 2003); Richard Reeves, President Nixon: Alone in the White House (New York: Simon and Schuster, 2001). An oral history documents President Nixon's "resentments" toward the press corps (see Deborah Hart Strober and Gerald S. Strober, The Nixon Presidency: An Oral History of the Era [Washington, DC: Brassey's, 2003], 45). Although not dealing exclusively with Nixon's relationship with the press, White House Chief of Staff H. R. Haldeman's diary supplies a contemporaneous account of the events under consideration in this article (see The Haldeman Diaries: Inside the Nixon White House [New York: G. P. Putman's Sons, 1994]).

\section{https://journalism-history.org}


13 For example, see Wafa Unus, A Newsman in the Nixon White House: Herbert Klein and the Enduring Conflict between Journalistic Truth and Presidential Image (Lanham, MD: Lexington Books, 2019); see also an analysis of verbal and nonverbal network coverage of the 1972 presidential campaign that found some basis for claims of editorial bias, though less so from ABC (Dennis T. Lowry, "Measures of Network News Bias in the 1972 Presidential Campaign," Journal of Broadcasting 18, no.4 [1974]: 387-402); more recently, Norman P. Lewis asserted that writers have, over time, mistakenly conflated one of Agnew's prominent speeches, in which he characterized critics as "nattering nabobs of negativism," with some of his other speeches in which he criticized the news media (Norman P. Lewis, "The Myth of Spiro Agnew's 'Nattering Nabobs of Negativism," American Journalism 27, 1 [2010]: 89-115); other scholarly treatments of Nixon's relationship with the press include William Earl Porter, Assault on the Media: The Nixon Years (Ann Arbor, MI: University of Michigan Press, 1976); and Louis W. Liebovich, Richard Nixon, Watergate, and the Press: A Historical Retrospective (London: Praeger, 2003).

14 Patrick J. Buchanan, Nixon's White House Wars: The Battles That Made and Broke a President and Divided America Forever (New York: Crown Forum, 2017). Klein served as Nixon's communications director and provided an account of the events leading up to and following Agnew's speech (see Making It Perfectly Clear); additionally, James Keogh, an aide and speechwriter, gives an account sympathetic to members of the Nixon administration and to those who believe the news media were biased against Nixon (see James Keogh, President Nixon and the Press [New York: Funk and Wagnalls, 1972]).

15 Jules Witcover, White Knight: The Rise of Spiro Agnew (New York: Random House, 1972); Jules Witcover, Very Strange Bedfellows: The Short and Unhappy Marriage of Richard Nixon and Spiro Agnew (New York: Public Affairs, 2007); Howard K. Smith, Events Leading Up to My Death (New York: St. Martin's Press, 1996); Barbara Matusow, The Evening Stars: The Making of the Network News Anchor (New York: Random House, 1983); Marc Gunther, The House That Roone Built: The Inside Story of ABC News (New York: Little, Brown, 1994).

16 From the Nixon Presidential Library and Museum in Yorba Linda, California, the article draws from the papers of Patrick J. Buchanan, James C. Hagerty, Harry R. Haldeman, W. Richard Howard, Herbert G. Klein, Richard M. Nixon, John A. Scali, and Ronald L. Ziegler. The author also consulted the following collections: Spiro Agnew (University of Maryland, College Park), Ed Bliss (American University, Washington, DC), Harry Chandler (Huntington Library, San Marino, CA), Charles Colson (Wheaton College, Wheaton, IL), Reuven Frank (Tufts University, Boston, MA), Leonard H. Goldenson (University of Southern California, Los Angeles, CA), Julian Goodman (Vanderbilt University, Nashville, TN), James Hagerty (Eisenhower Presidential Library, Abilene, KS), Elmer W. Lower (University of Missouri, Columbia, MO), Dan Rather (Howard Gotlieb Archival Research Library, Boston University, Boston, MA), Frank Reynolds (Georgetown University, Washington, DC), and Avram Westin (Wisconsin Historical Society, Madison, WI). Additionally, the author drew on oral history interviews and conducted interviews with Elmer Lower, Irving Fang, William Sheehan, Howard K. Smith, and Av Westin.

\section{https://journalism-history.org}


17 Remarks of Richard Nixon, Beverly Hilton, Nov. 7, 1962, box 64, PPS 208, Richard Nixon Presidential Library and Museum, Yorba Linda, California (henceforth cited as RNPLM); Norman Chandler to William Benton, Nov. 23, 1962, and Norman Chandler to P. W. Reeves, March 1, 1963, box 217, folder 16, Norman Chandler Papers, Los Angeles Times Records, Huntington Library, San Marino, California; Richard Nixon, The Memoirs of Richard Nixon (New York: Grosset and Dunlap, 1978), 246.

18 Patrick Buchanan, The Greatest Comeback: How Richard Nixon Rose from Defeat to Create the New Majority (New York: Crown Forum, 2014), 1. "The Political Obituary of Richard Nixon" was broadcast on Howard K. Smith News and Commentary on ABC Television, Nov. 11, 1962. Smith described writing with Hagerty at his elbow in an interview with the author, Aug. 1, 2001, Bethesda, MD (recording and transcript in author's possession). See also Smith, Events Leading Up to My Death, 291.

19 Buchanan, Greatest Comeback, 13, 1. Joe McGinniss wrote that Nixon considered television "a gimmick" and one more way to make him look silly." See Joe McGinniss, The Selling of the President (New York: Simon and Schuster, 1969), 33. For the administration's unfavorable opinion of the book, see Clark Mollenhoff to Bob Haldeman, Oct. 22, 1969, box 33, folder 6, H. R. Haldeman Papers, White House Special Files (henceforth cited as WHSF): Staff Member and Office Files (henceforth cited as SMOF), RNPLM (henceforth cited as Haldeman Papers).

20 Ward Just, "The Perils of Spiro," Washington Post, Sept. 25, 1968. This editorial on Agnew was later remembered as "one of the Post's most biting pieces of political commentary." See Harrison Smith, "Ward Just, Washington Post Reporter and Acclaimed Political Novelist, Dies at 84," Washington Post, Dec. 19, 2019.

21 For condemnation of black student protestors, see Spiro T. Agnew, "Opening Statement, Conference with Civil Rights and Community Leaders," April 11, 1968, box 3, series II, Agnew Papers; see also Witcover, White Knight, 21. Agnew's comments on the Kerner Commission report are found in Spiro T. Agnew, "Statement to Executive Session," National Governors' Conference, Cincinnati, OH, July 23, 1968, box 4, series II, Agnew Papers.

22 "Agnew Explains 'Polack' and 'Jap," New York Times, Sept. 24, 1968. See also Witcover, White Knight, 252-63; and Klein, Making It Perfectly Clear, 160. The reference to slums is found in Reeves, President Nixon, 147.

23 Agnew's comment on offending all groups is found in "Transcript of Remarks by Governor Spiro T. Agnew, National Press Club, Sept. 27, 1968, box 4, series II, Agnew Papers. Agnew’s "village idiot" comment is found in Keogh, President Nixon and the Press, 2.

24 In a number of form letters, Agnew's administrative assistant wrote, "The Vice President believes that during the campaign the press used him as a lightning rod rather than to attack Mr. Nixon directly." For example, see C. Stanley Blair to Barbara Rousseau, Nov. 28, 1969, box 144, series III, Agnew Papers.

25 Marshall, Watergate's Legacy and the Press, 59; Witcover, Very Strange Bedfellows, 86-88.

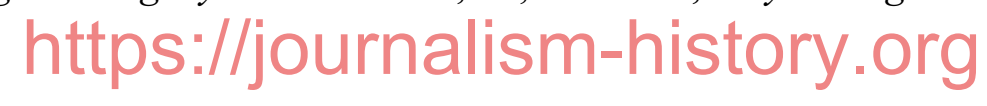


26 Klein, Making It Perfectly Clear, 166. For “Nixon's Nixon," see Greenberg, Nixon's Shadow, 145. Buchanan wrote of the "Robespierre" characterization in Nixon's White House Wars, 81. Buchanan explained why Agnew was effective on the attack in Buchanan to Haldeman, Sept. 25, 1968, WHSF (returned), box 26, folder 8, RNPLM.

27 Spiro T. Agnew, Go Quietly . . . Or Else (New York: William Morrow, 1980), 26. Safire makes reference to "Spiro, our hero" in "Agnew or Bust," New York Times, March 13, 1995. Reference to the bumper stickers is made in "Spiro T. Agnew, Ex-Vice President, Dies at 77," New York Times, Sept. 18, 1996. Reference to a Gallup poll is made in "Nixon Heads List of "'Admired Men," New York Times, Jan. 4, 1970. A subsequent poll showed Agnew becoming even more popular (see “Mayor and Agnew Gain, Gallup Says,” New York Times, Feb. 8, 1970).

${ }^{28}$ Louis W. Leibovich, Richard Nixon, Watergate, and the Press (London: Praeger, 2003), 1. For Safire's recollection, see Sarah Weber, "Spiro Agnew Showed How to Attack the Media," Editor and Publisher, July 17, 2006. Nixon's admonition to Kissinger and Haig were captured on audio tape (see Conversation 823-1, Tape Subject Log, RNPLM); see also Dan Glaister, "Tricky Dick: Nixon Recordings Confirm Popular View," The Guardian, Dec. 3, 2008). Nixon's comments to his cabinet are referenced in Dick Adler, "The White House vs. Television News: You Make Yourself the Enemy They See," May 15, 1974, reprinted from the Los Angeles Times, box 109, folder 8, mss. 0880, Julian Goodman Papers, Vanderbilt University Special Collections, Nashville, TN (henceforth cited as Goodman Papers). Pressman's characterization is found in On Press, 197.

29 McGinniss, Selling of the President, 34; Bruce Oudes, ed., From the President: Richard Nixon's Secret Files (New York: Harper and Row, 1989); Edwin Diamond, "How the White House Keeps Its Eye on the Network News Shows," New York, May 10, 1971, 45-49.

${ }^{30}$ Herbert Klein, “Memorandum for H. R. Haldeman,” June 3, 1969, box 1, H. R. Haldeman I [1 of 3], WHSF: SMOF: Herbert G. Klein, RNPLM (henceforth Klein Papers).

31 Jeb Magruder to Haldeman and Klein, "The Shotgun versus the Rifle: Confidential, Eyes Only," Oct. 17, 1969, box 17, folder 7, Charles Wendell Colson Papers, Billy Graham Center Archives, Wheaton College, Wheaton, IL (henceforth cited as Colson Papers).

32 See Rodney A. Smolla, Free Speech in an Open Society (New York, Vintage, 1993), 322-24; and Thomas Streeter, Selling the Air: A Critique of the Policy of Commercial Broadcasting in the United States (Chicago, IL: University of Chicago Press, 1996), 141.

33 Lyn Nofziger to Bryce Harlow, Sept. 29, 1969, box 17, folder 7, Colson Papers; Dick Adler, “The White House vs. Television News: Administration Seeks Bias, Balance," May 14, 1974, reprinted from the Los Angeles Times, box 109, folder 8, Goodman Papers.

34 Walter Pincus and George Lardner Jr., "Nixon Hoped Antitrust Threat Would Sway Network Coverage," Washington Post, Dec. 1, 1997.

\section{https://journalism-history.org}


35 "Mr. Nixon in Trouble," Newsweek, Oct. 13, 1969, 30; David Broder, “A Risky New American Sport: The Breaking of the President," Washington Post, Oct. 7, 1969; "Question and Answer with Pat Buchanan,” May 25, 2017, C-SPAN, c-span.org/video/transcript/?id=55942.

36 See Being Nixon: A Man Divided (New York, Random House, 2015), 240. Buchanan claimed he first suggested the "silent majority" in a memo he wrote on Aug. 31, 1968, in which he suggested that Nixon make a contrast between noisy demonstrators and "quiet Americans." See Buchanan, Greatest Comeback, 328. Safire noted that the term "silent majority" was "an old phrase meaning dead people." To join the silent majority, he said, meant "to die and go on and become part of a cemetery." See William Safire, interview by Timothy Naftali, March 27, 2008, 8, transcript, Oral Histories, RNPLM.

37 Perlstein, Nixonland, 437.

38 Nixon to Haldeman, Oct. 26, 1969, box 1, file 11, President's Personal Files, WHSF: SMOF, RNPLM; Haldeman, handwritten notes, Nov. 3, 1969, box 40, folder Oct. 1 to Dec. 31, 1969, Haldeman Papers.

39 Richard Nixon, "Vietnam Speech, RN Reading Copy" Nov. 3, 1969, box 52, folder 18, President's Speech File, 1969-1970, RNPLM.

40 Karlyn Kohrs Campbell, The Great Silent Majority: Nixon's 1969 Speech on Vietnamization (College Station, TX: Texas A\&M University Press, 2014), 43.

${ }^{41}$ Campbell, Great Silent Majority, 21.

42 “Gallup Reports 77\% Back Nixon: Telephone Survey Taken after Vietnam Speech,” New York Times, Nov. 5, 1969.

43 Nixon, Memoirs of Richard Nixon, 409; Stephen Ambrose, Nixon: The Triumph of a Politician (New York: Simon and Schuster, 1989), 310. For the perceived effectiveness of the speech see Haldeman to Safire, Nov. 21, 1969, box 55, folder 8, Haldeman Papers. For Nixon's post-speech directives see Haldeman to Klein, Nov. 21, 1969, box 55, folder 2, Haldeman Papers and President to Haldeman, Nov. 24, 1969, box 1, folder 12, President's Personal Papers, RNPLM.

44 “Thirty Minutes With.” Interview with Patrick J. Buchanan, May 4, 1972, Public Broadcasting Service, transcript, box 5, WHSF: SMOF: W. Richard Howard Papers, RNPLM (henceforth cited as Howard Papers).

45 Reeves, President Nixon, 147; and Keogh, President Nixon and the Press, 171-81.

46 Haldeman, Haldeman Diaries, 104.

47 Keogh, President Nixon and the Press, 44. Mention of the dossier is made in "Agnew's Complaint: The Trouble with TV," Newsweek, Nov. 24, 1969, 89.

48 Perlstein, Nixonland, 436.

\section{https://journalism-history.org}


${ }^{49}$ McGinniss, Selling of the President. McGinniss wrote of the need for voters to see "something new; not this scarred, discarded figure from their past" but someone with a "new stability" (34). Nixon himself made reference to his "new" image in a taped question-and-answer broadcast in Chicago (70).

50 Klein, "Memorandum to the President," Nov. 5, 1969, Hagerty alpha file, WHSF, RNPLM. See also Jack Gould, "Burch Calls Networks on Nixon Speech," New York Times, Nov. 14, 1969.

51 “Question and Answer with Pat Buchanan,” May 25, 2017, C-SPAN.

52 Buchanan's claims that the memo was among his most consequential is found in Buchanan, Nixon's White House Wars, 69. The memo, Buchanan to the President, Nov. 5, 1969, is reproduced, with Haldeman's notation, as a color plate in the same book. Reeves wrote that Buchanan suggested, "Let Agnew go after these guys" (President Nixon, 147).

53 Liebovich, Richard Nixon, Watergate, and the Press, 7.

54 E. W. Kenworthy, “Agnew Says TV Networks Are Distorting the News," New York Times, Nov. 14, 1969.

55 “Question and Answer with Pat Buchanan,” May 25, 2017, C-SPAN.

56 Klein, Making It Perfectly Clear, 172.

57 Haldeman, Haldeman Diaries, 28; Agnew, Go Quietly . . Or Else, 28.

58 Consideration of paying for television air time is found in Haldeman handwritten notes, Nov. 11 and 12, 1969, box 40, folder Oct. 1, 1969 to Dec. 31, 1969, Haldeman Papers. The Des Moines Register recalled the quote from its contemporaneous coverage in "Fifty Years AgoSpiro Agnew and the 'Des Moines' Speech," Des Moines Register, Nov. 10, 2019. According to an audio recording of the vice president's introductory remarks, he claimed that he had planned all along to attend the conference, along with other regional meetings the Republicans had scheduled. See "Spiro T. Agnew, TV News Coverage," American Rhetoric, americanrhetoric.com/speeches/spiroagnewtvnewscoverage.htm. However, according to the New York Times, none of the party's conference planners expected what was to come next. See Seth S. King, "Vice President's Speech Was Scheduled at His Request Only Two Days Earlier," New York Times, Nov. 15, 1969, 20. Further conference details are found in Ernie Minor to Agnew, Nov. 11, 1969, box 128, series III, Agnew Papers.

59 The speech texts were sent to the three networks' Washington bureau chiefs, wire services, major newspapers, Chicago newspapers, and key members of Congress. See Klein to Haldeman, Nov. 12, 1969, box 128, series III, Agnew Papers.

60 Agnew to Smith and Smith to Agnew, both dated Nov. 13, 1969, box 128, series III, Agnew Papers.

\section{https://journalism-history.org}


61 Klein, Making It Perfectly Clear, 171. The steps Klein planned to take to notify the networks and newspapers are found in a memorandum to Haldeman, Nov. 12, 1969, box 1, H. R. Haldeman I [2 of 3], Klein Papers.

62 In a radio interview, $\mathrm{ABC}$ executive producer Av Westin described how ABC News, similar to the other networks, produced multiple feeds of each newscast in order to accommodate affiliated stations in various time zones (see Av Westin, interview by Bill Mazor, WOR Radio interview, Nov. 26, 1969, tape 509A, Avram Westin Papers, Wisconsin Historical Society, Madison, WI [henceforth cited as Westin Papers]).

63 Klein claimed that $\mathrm{ABC}$ announced first that it would use a local public television station's black-and-white feed and that CBS and NBC then followed. NBC News president Reuven Frank disputed that claim. See Klein, Making It Perfectly Clear, 171; and Reuven Frank, Out of Thin Air: The Brief Wonderful Life of Network News (New York: Simon and Schuster, 1991), 294.

64 Billy Jackson, interview with Pat Buchanan, Dec. 29, 2007, McLean, VA, recording and transcript in author's possession.

65 See "Spiro T. Agnew, TV News Coverage," American Rhetoric.

66 Agnew, "Speech to Mid-West Regional GOP Committee Meeting," Nov. 13, 1969, Des Moines, IA, box 128, series III, Agnew Papers.

${ }^{67}$ Kenworthy, “Agnew Says TV Networks Are Distorting the News.” Inside, the newspaper used an entire inside page to reprint the full text of Agnew's speech.

68 Christopher Lydon, "Burch Supports Agnew; Shift in F.C.C. Role Seen," New York Times, Nov. 15, 1969.

69 See Lydon, "Burch Supports Agnew." Klein wrote that he had made the request of Burch on Colson's behalf, asserting that he was "not aware how unusual it was for the Federal Communications chairman to seek transcripts." See Klein, Making It Perfectly Clear, 173-74. Perlstein noted that Klein also suggested that local television stations be monitored as well. See Perlstein, Nixonland, 437. See also Jack Gould, "Burch Calls Networks on Nixon Speech," New York Times, Nov. 14, 1969; Lucas A. Powerades, American Broadcasting and the First Amendment (Berkeley, CA: University of California Press, 1987), 124; and David Wise, The Politics of Lying: Government Deception, Secrecy, and Power (New York: Random House, 1973), 259.

70 Keogh, President Nixon and the Press, 139.

71 Robert Metz, CBS: Reflections in a Bloodshot Eye (New York: Signet Book, 1975), 266-69.

72 See ABC Evening News with Frank Reynolds and Howard K. Smith, Nov. 14, 1969, box 12, folder 62, Frank Reynolds Papers, Georgetown University Library, Booth Family Center for Special Collections, Washington, DC (henceforth cited as Reynolds Papers).

\section{https://journalism-history.org}


73 Smith, ABC Evening News with Frank Reynolds and Howard K. Smith, Nov. 18, 1969, box 11, Topical-Agnew, Edward Bliss Papers, American University Special Collections, Washington, DC (henceforth cited as Bliss Papers).

74 Reynolds, ABC Evening News with Frank Reynolds and Howard K. Smith, Nov. 21, 1969, box 12, folder 63, Reynolds Papers.

75 Haldeman handwritten notes, Nov. 14, 1969, box 40, folder Oct. 1, 1969 to Dec. 31, 1969, Haldeman Papers. Nixon ordered a private poll on Agnew's popularity, though he instructed, "Avoid at all costs any indication to Agnew that I ordered the poll taken on his popularity" (President to Haldeman, Nov. 24, 1969, box 1, folder 12, President's Personal Papers, RNPLM).

76 “Agnew and TV News: The Dirty 'Dozen,"” Women's Wear Daily (Nov. 17, 1969), 8-9; “The Unelected Elite," Time, Nov. 21, 1969, 20; "The Faces of Faceless Men," Newsweek, Nov. 24, $1969,92$.

77 Witcover, Very Strange Bedfellows, 76. See also Roger Wetherington, “Klein: Agnew'll Quit Press War," Daily News, Nov. 18, 1969, box 116, Spiro T. Agnew Correspondence, 1969-1972, James Hagerty Papers, Dwight D. Eisenhower Presidential Library, Abilene, KS (henceforth cited as Hagerty Papers).

78 Charles Colson, "Random Notes about the First Three Weeks" (handwritten notes), Nov. 22, 1969, box 13, folder 11, Colson Papers.

79 Klein's objections are found in Klein to Haldeman, Nov. 19, 1969, box 55, folder 2, Haldeman Papers. Zieglers objections are found in Ziegler to Haldeman, Nov. 20, 1969, box 1, Agnew Speech, WHSF: SMOF, Ronald Ziegler Papers, RNPLM (henceforth cited as Ziegler Papers). Ziegler's proposed revision is found in alternate draft of speech, Nov. 20, 1969, box 1, Agnew Speech, Ziegler papers.

80 "Address by the Vice President, Montgomery Chamber of Commerce, Nov. 20, 1969, box 129, series III, Agnew Papers.

81 “Leonard Goldenson Statement," box 1, Agnew Speech (November 1969), Ziegler Papers.

82 News Summary, Nov. 27, 1969, WHSF: President's Office File, box 31, News Summaries, November 1969, RNPLM.

83 For examples, see "Agnew Charges Media Go Easy on Communism," Broadcasting, March 23, 1970) and "Text of Agnew's Speech Scoring the Press," New York Times, May 23, 1970.

84 Westfeld and Westin, interview by Mazor, WOR Radio, Nov. 26, 1969, tape 509A, Westin Papers.

85 Hagerty to Goldenson, Nov. 20, 1969, box 16, Spiro T. Agnew Correspondence, 1969-1972, Hagerty Papers.

\section{https://journalism-history.org}


86 Elmer W. Lower, "Fairness and Balance in Television News Reporting," address to Phi Delta Phi Fraternity, Dec. 10, 1969, Columbia University School of Law, box 1, folder 41, Elmer W. Lower Papers, Special Collections, University of Missouri, Columbia, MO (henceforth cited as Lower Papers).

87 Irving Fang, interview by author, Oct. 23, 2009, St. Paul, MN. Recording and transcript in author's possession.

88 Lower, "Fairness and Balance in Television News Reporting." In May 1979, Lower told an Ohio University audience that the Nixon administration had conducted its own content analysis and reached similar results. See Elmer W. Lower, "Problems and Obligations of Broadcast News," May 6, 1979, box 17, folder 45, Reynolds Papers.

89 The record makes clear that Hagerty remained in contact with Eisenhower and other Republicans. Agnew wrote to Hagerty, "Thank you very much for sending me the remarks of Elmer Lower. . . I I read them with considerable interest.” See Agnew to Hagerty, Dec. 18, 1969, box 116, Spiro T. Agnew Correspondence, 1969-1972, Hagerty Papers.

90 Agnew to Hagerty, Dec. 18, 1969, box 116, Spiro T. Agnew Correspondence, 1969-1972, Hagerty Papers.

91 Hagerty to Agnew, Jan. 7, 1970 and Agnew to Hagerty, Jan. 29, 1970, both in box 116, Spiro T. Agnew Correspondence, 1969-1972, Hagerty Papers.

92 Hagerty to Ziegler, Dec. 31, 1969, box 11, Herb Klein and Ron Ziegler Correspondence, 1968-1969, Hagerty Papers.

93 J. Edgar Hoover, "How J. Edgar Hoover Felt about TV's 'The FBI,"” TV Guide, May 20-26, 1972.

94 J. Edgar Hoover to Goldenson, Jan. 16, 1970, box 110, Dwight D. Eisenhower Correspondence, Hagerty Papers. Hoover sent a copy of the letter to Hagerty, along with a note that their friendship had "always been a source of inspiration" (see Hoover to Hagerty, Jan. 16, 1970, box 110, Hagerty Papers).

${ }^{95}$ Haldeman to Klein and Ziegler, Nov. 17, 1969, Dan Rather Papers, Howard Gotlieb Archival Research Library, Boston University, danratherjournalist.org/political-analyst/white-housecorrespondent/nixon-administration/compilation-nixon-and-press-2 (henceforth cited as Rather Papers).

96 Haldeman to Klein, Nov. 25, 1969, box 55, folder 2, Haldeman Papers.

${ }^{97}$ Klein, "Memorandum for the President," Dec. 5, 1969, box 3, Memos to the President, 1969, Klein Papers.

98 Ziegler to Haldeman, Nov. 25, 1969, Rather Papers.

\section{https://journalism-history.org}


99 Klein to the President, Feb. 19, 1970, box 3, memoranda to the President I [3 or 3], Klein Papers.

100 Klein, Memorandum for the President, Jan. 22, 1970, box 3, Memos to the President I [3 of 3], Klein Papers.

${ }^{101}$ Edith Efron, “There Is a Network News Bias,” TV Guide, Feb. 28, 1970.

102 Larry Higby to Magruder, March 4, 1970, box 1, H. R. Haldeman I [3 of 3], Klein Papers. See also "News Bias as Howard K. Smith Sees It," Republican Congressional Committee Newsletter, Mar. 9, 1970, box 148, HRH-Political 1970, Haldeman Papers.

103 Colson to Haldeman, Sept. 25, 1970, box 68, folder 9, Colson Papers.

104 Colson to Haldeman, Sept. 25, 1970.

105 Nixon to Goldenson, Sept. 16, 1970; Goldenson to Nixon, n.d. (draft copy), box 116, RN Correspondence, 1967-1973, Hagerty Papers.

106 Matusow, Evening Stars, 176.

107 Sheehan, interview with author, Aug. 2, 2001 (Recording and transcript in author's possession).

108 Smith, interview with author.

109 Smith, Events Leading Up to My Death, 350.

110 The nationally televised interview was conducted with Smith, John Chancellor of NBC, Eric Sevareid of CBS, and Nancy Dickerson of PBS (see President's Daily Diary, Jan. 4, 1971, RNPLM). Colson's report of his lunch with Smith is found in Memorandum for Ron Ziegler, Jan. 8, 1971, box 18, folder 147, Ziegler Papers.

111 Reynolds, ABC Evening News with Frank Reynolds and Howard K Smith, Feb. 27, 1970, box 12, folder 60, Reynolds Papers.

112 See Dale L. Cressman, "A Biographical Study of Television News Pioneer Elmer W. Lower" (PhD diss., University of Utah, 2003). See also Matusow, Evening Stars, 175. Matusow reports that $\$ 8$ million was cut from a $\$ 40$ million budget.

113 Westin, interview with author, Oct. 29, 2001, New York City (recording and transcript in author's possession). For the threat of replacing the newscast with a syndication feed, see also Matusow, Evening Stars, 175. By spring 1970, Lower was able to report that the number of ABC affiliates carrying the news broadcast had grown to 130 (Elmer W. Lower, speech to the National Association of Broadcasters, April 5, 1970, Chicago, box 1, folder 46, Lower Papers).

114 Sheehan, interview.

\section{https://journalism-history.org}


115 Elmer Lower Oral History (2000), 197-98, series 19, C:0/46/60 (A07-115), 1 vol., 725, 1, 3 small holdings box 1, University of Missouri Archives.

116 Gunther, House That Roone Built, 73.

117 Ken W. Clawson, "FBI's Hoover Scores Ramsey Clark, RFK," Washington Post, Nov. 17, 1970.

118 Reynolds, ABC Evening News, Nov. 19, 1970, box 11, folder 62, Reynolds Papers. See also Milton A. Jones, memorandum to Thomas Bishop, Nov. 20, 1970, file 094-HQ-60750 (unserialized), Federal Bureau of Investigation (henceforth cited as FBI).

119 Erick Trickey, "Inside the Intense Rivalry between Eliot Ness and J. Edgar Hoover," Smithsonian Magazine, Oct. 2014.

120 Bishop to Jones, Nov. 21, 1970, file 094-HQ-60750-117, FBI.

121 Jones to Bishop, Nov. 23, 1970, file 94-60750-1116, FBI. As of 2020, the FBI has redacted Pompadur's name; however, he is also identified in reporting by David Robb, "Media Jobs, Rights Under FBI Thumb in Security History of TV Show," Hollywood Today, Feb. 28, 2008.

122 Telephone message, Nov. 23, 1970, file 094-HQ-60750 (unserialized), FBI.

123 The meeting is memorialized in a five-page document. Jones to Bishop, 094-HQ-60750 (unserialized), FBI.

${ }^{124}$ Frank Reynolds Commentary, ABC Evening News, Dec. 4, 1970, box 12, folder 65, Reynolds Papers. Reynolds worked as ABC's White House correspondent until he returned to the coanchor position in 1978. See Frank J. Prial, "Frank Reynolds, ABC Newsman, Dies," New York Times, July 21, 1983.

125 Smith, interview with author.

126 Harry Reasoner, Before the Colors Fade (New York: Alfred A. Knopf, 1981), 183.

127 Buchanan to the President, Nov. 18, 1970, box 49, folder 41, WHSF contested, RNPLM.

128 The aide was John Scali, who agreed that Reasoner's commentary amounted to a "very cheap shot." See Higby to Colson, May 1, 1972, box 1, folder 6, Scali Papers; Colson to John Scali, May 2, 1972, box 1, folder 6, WHSF: SMOF: John A Scali, RNPLM (henceforth cited as Scali Papers).

${ }^{129}$ ABC was represented by Goldenson, Simon Siegel, Everett Erlick, Hagerty, and Lower. See Colson, "Memorandum for the President's File: Meeting with ABC Executives, Jan. 28, 1971, 4:15 pm," Feb. 5, 1971, box 68, folder 9, Colson Papers. Smith noted that he did, in fact, interview Nixon on March 22, 1971, "the first one-on-one interview with a President ever broadcast on TV" (Smith, Events Leading Up to My Death, 293).

\section{https://journalism-history.org}


130 Two years later, Nixon appointed Scali to replace George H. W. Bush as ambassador to the United Nations. Scali rejoined ABC News in 1975 and reported for the network until 1993. See Lawrence Van Gelder, "John A. Scali, 77, ABC Reporter Who Helped Ease Missile Crisis," New York Times, Oct. 10, 1995.

131 Ziegler to Haldeman, Nov. 25, 1969, Rather Papers.

132 Nixon to Goldenson, April 19, 1971, box 116, RN Correspondence, 1967-1973, Hagerty Papers.

133 Charles W. Colson, Born Again (Grand Rapids, MI: Chosen, 1976), 52; Walter Isaacson, Kissinger: A Biography (New York: Simon and Schuster, 2005), 328.

134 Until 1971, the networks were unaware that the White House logged press coverage and produced news summaries (see Frank Jordan to Reuven Frank, April 5, 1971, box 3, Reuven Frank Papers, Tufts University, Boston).

135 Scali to Colson, "Eyes Only: ABC Coverage of Laos and Administration Critics," April 14, 1971, box 1, folder 5, Scali Papers.

136 Scali to Colson, April 15, 1971, box 1, folder 5, Scali Papers.

137 Scali, "Memorandum for the President," May 11, 1971, box 5, folder 2, Scali Papers.

138 Reaction to Reasoner is cited in Colson to Scali, Aug. 4, 1972, box 1, folder 6, Scali Papers. Cioffi reporting is cited in News Summary, Jan. 3, 1973, box 53, Unmarked News Summaries, WHSF: President's Office Files, RNPLM. Nixon notations are found in Memorandum for John Scali, Jan 5, 1973 (with attached excerpt of a Jan 3, 1973 news summary), box 1, folder 5, Scali Papers.

139 Buchanan, Nixon's White House Wars, 52.

140 Chester Pach, "Our Worst Enemy Seems to Be the Press': TV News, the Nixon Administration, and U.S. Troop Withdrawal from Vietnam, 1969-1973," Diplomatic History 34, 3 (2010): 564.

141 Scali to Haldeman, "My Memo to President, June 27, Re: Presidential Memo-News Media," July 21, 1972, box 5, folder 1, Scali Papers.

142 John Scali, “Memo for File: Conversation with Bob Haldeman,” July 26, 1972, Scali Papers.

143 Robert A. Wright, “Agnew Suggests Accord to Press,” New York Times, July 23, 1972.

144 Scali, “Memo for File: Conversation with Bob Haldeman,” July 26, 1972, Scali Papers.

145 Tom Brokaw, The Fall of Richard Nixon: A Reporter Remembers Watergate (New York: Random House, 2019), 48.

\section{https://journalism-history.org}


146 ABC Evening News with Howard K. Smith and Harry Reasoner, Oct. 31, 1973. Cited in Bliss, Now the News, 414. For Smith's subsequent recollection see Events Leading Up to My Death, 254.

147 Magruder to Chapin, Jan. 8, 1971, Hagerty alpha file, SMOF, RNPLM.

148 Reynolds to Edward Bliss Jr., Aug. 4, 1978, box 7, Biographical-Reynolds, Bliss Papers.

149 Gunther, House That Roone Built, 73.

150 Epstein, "The Bias of Network News," Imprimis 3, 1 (1974), imprimis.hillsdale.edu/the-biasof-network-news. Sheehan characterized the claim as "all myth and rumor" and "probably spread by a competitor." (See Adler, "White House vs. Television News: The Search for a Truce Seeker," May 16, 1974, reprinted from the Los Angeles Times, box 109, folder 8, Goodman Papers.)

151 Adler, "The White House vs. Television News: Administration Seeks Bias, Balance.”

152 Adler, "The White House vs. Television News: The Search for a Truce Seeker."

153 Donovan and Scherer, Unsilent Revolution, 118; Socolow, "Agnew Speeches Sparked Move toward Soft News"; Socolow, "A Profitable Public Sphere: The Creation of the New York Times Op-Ed Page," Journalism and Mass Communication Quarterly 87, 2 (2010): 281-96.

${ }^{154}$ Adler, "The White House vs Television News: Tactics Change, but the War Goes On," May 13 1974, reprinted from the Los Angeles Times, box 109, folder 8, Goodman Papers.

\section{https://journalism-history.org}

